\title{
The problem of migration security in the current case-law of the CJEU - the perspective of Member States ${ }^{1}$
}

\section{Introductory remarks}

The aim of the current article is the analyze the role of the CJEU in providing migration security of the EU Member States (MS) and consequently to the whole Union in the face of the migration crisis. ${ }^{2}$ Given the increased influx of migrants from third countries, which began in April 2015, it turned out that the existing legal instruments in the area of asylum and return law are not sufficient given the actual migration challenges. The Union has undertaken a number of reforms, which, however, are of a longterm character and it may take some time before they produce desired effects. ${ }^{3}$

On an introductory note, it is also worth referring to the current statistics with regard to migration into the Member States - in 2018, in accordance with the EASO data, 634,700 asylum applications were filed, which is almost a half less than in 2015. The main countries of origin included Syria, Afghanistan, Pakistan and Iran (Latest asylum trends, 2018). What is more difficult to represent with the use of statistics is the data with regard to irregular migration - in 2018, in accordance with the data provided by Frontex, 361,636 third-country nationals were identified as residing illegally within the territory of the MS (for the sake of comparison, in 2017 there were over 435,000 of such persons), 286,875 return decisions were issued and 148,121 returns were put into force (Risk Analysis for 2019, p. 52).

In accordance with the thesis proposed in the current article, the CJEU does have the real possibility for shaping the standards of migration security in the area of asylum and return policy through its case-law. ${ }^{4}$ The cases examined by the Court of Justice

1 The current article is based on the findings of the research project entitled "Zarządzanie bezpieczeństwem w prawie i polityce azylowej i powrotowej Unii Europejskiej w obliczu kryzysu migracyjnego" (Security management in European asylum and return law and policy with regard to the migration crisis) registered at No. 2016/23/D/ HS5/00404 and funded by the National Science Centre, Poland.

${ }^{2}$ On the subject of the threats resulting from migration, see: Fehler, Cebul, Podgórzańska, 2017, p. 56. See also: Stawicki, 2019, p. 90 et seq.

${ }^{3}$ See for instance: Proposal for a Regulation of the European Parliament and of the Council on standards for the qualification of third-country nationals or stateless persons as beneficiaries of international protection, for a uniform status for refugees or for persons eligible for subsidiary protection and for the content of the protection granted and amending Council Directive 2003/109/EC of 25 November 2003 concerning the status of third-country nationals who are long-term residents, COM/2016/0466 final - 2016/0223 (COD).

${ }^{4}$ The cases are brought before the Court of Justice primarily within the procedure of questions referred for a preliminary ruling, in accordance with Art. 267 TFEU (Treaty on the Functioning). 
provide a unique benchmark for the challenges and legal issues in the Area of Freedom, Security and Justice. Thus, the analysis of the case-law of the Court of Justice issued after 2015 regarding the security of the Member States should be conducive to providing a diagnosis of the basic challenges in the area of ensuring legal security to asylum and return migrants.

In accordance with the thesis adopted for the purpose of the research project, there exists a principle of the migration security priority, in accordance with which it is necessary to guarantee the highest level of security to all the actors of the migration process, that is to both migrants themselves, as well as the receiving society. This should occur both at the level of legislation and at the level of the application of the law (Kosińska, 2017, pp. 101-128). ${ }^{5}$

The methodology adopted in the current article relies on the methods typical of legal sciences (the legal-dogmatic and hermeneutical method). Due to the extent of the case-law of the CJEU with regard to the issue under discussion, only selected cases came under scrutiny in the current study - those, according to the author, which were key for the analysis of the subject matter. The article presents part of the research findings of the project regarding the CJEU's case-law. The remaining results will be published in separate articles on the issues of the protection of migrants' rights $^{6}$ and the case-law concerning the Dublin cases. ${ }^{7}$

\section{The CJEU case-law with regard to the security of the Member States}

On the basis of the analyzed case-law of the CJEU, one can identify the following issues:

First of all, the Court examined the cases directly related to the protection of the national security and public order. In the case of J.N. the Court examined the appropriateness of detention of a person seeking international protection (Case C 601/15 PPU). The proceedings concerned a foreign national who had resided in the Netherlands since the 1990s, had several convictions by a criminal court for the committed crimes, had an entry ban ordered by a court and decided to lodge another, a fourth one, application for international protection. The national authorities decided that detaining the foreign national was necessary for the protection of national security and public order. The Court investigated, as part of the preliminary ruling procedure, whether such detention lies within the meaning of Art. 6 Charter of Fundamental Rights (the right to liberty and security of person). In the judgement the Court reminded that "In observance of the principle of proportionality, limitations may be imposed on the exercise of those rights and freedoms only if they are necessary and genuinely meet objectives of general interest recognised by the European Union or the need to protect the rights

${ }^{5}$ On the subject of the correlation between the phenomenon of migration and security, see: Gierszewski, Pieczywok, 2019, p. 62 et seq; Wawrzyk, 2014, p. 233; Ahmed, 2017, pp. 373-375.

${ }^{6}$ Cases C 652/16, C 581/1, C 652/16, C 56/17, C 646/16, C 638/16, C 353/16, C 180/17, C 695/15, C 404/17, C 560/14, C 348/16, C 181/16, C 175/17, C 18/16.

${ }^{7}$ Cases C 646/16, C 490/16, joined C 47/17 and 48/17, C 647/16, C 670/16, C 661/17, C 327/18, joined C 391/16 and C 77/17 and C 78/17. 
and freedoms of others" and in the opinion of the Court, the possibility of detaining a person seeking protection, under Art. 8(3)(e) directive 2013/33 (detention for the protection of security and public order) does not infringe the right to liberty under Art. 6 CFR, but serves the purpose of protecting the general interest (Case 601/15 PPU, para. 52). The Court also emphasized that " “...the detention of an applicant where the protection of national security or public order so requires is, by its very nature, an appropriate measure for protecting the public from the threat which the conduct of such a person represents" (Case 601/15 PPU, para. 55). ${ }^{8}$ However, in each case it is necessary to conduct an individual and in-depth examination of the behaviour of the person on whom a limitation of freedom in the form of detention measures is imposed.

In a similar way, detention was the concern of the case of $\mathrm{K}$, in which the Court referred directly to the judgement in the case of J.N. The proceedings in the case of K concerned a third-country national, who was detained at the airport under the suspicion of using a false passport. Next, the foreign national filed an application for international protection and was further detained for the verification of his identity. The reason for the detention was dictated by the necessity of ensuring the proper functioning of the CEAS and in the opinion of the Court met the requirement od proportionality and was not contradictory to the standards of protection under Art. 6 CFR (Case C 18/16). ${ }^{9}$

The issues of the threat to security and public order which might be posed by a third-country national were also the concern of the case of E (Case C 240/17). The proceedings in this case concerned a national of Nigeria, who identified himself by means of a residence permit issued in Spain, whereas in the territory of Finland he committed an offence for which he was sentenced to imprisonment and further, he was issued a return decision and an entry ban on the grounds of him posing a threat to security and public order. The competent Finnish authorities made an attempt to consult the Spanish authorities with a view to withdrawing the residence permit of the foreign national but they could not reach an agreement on that matter. The question referred for a preliminary ruling concerned the interpretation of the legal consequences of the obligation of the consultation between the bodies of the Member States as provided for in the implementing Convention of the Schengen Agreement. In its judgement, the Court emphasized that the Finnish authorities, taking into consideration the legal circumstances of $\mathrm{Mr} \mathrm{E}$, were obligated to issue a decision imposing on the applicant a decision to return on the grounds of Art. 6 (2) Directive 2008/115; ${ }^{10}$ however, they were

${ }^{8}$ Moreover, the Court presented in the case under discussion the definition of the concept of public order: "the concept of 'public order' entails, in any event, the existence - in addition to the disturbance of the social order which any infringement of the law involves - of a genuine, present and sufficiently serious threat affecting one of the fundamental interests of society" (para. 65 of the judgement). The Court also referred to the existing case-law in this matter. Moving further, public security, in the understanding of the Court, "covers both the internal security of a Member State and its external security and that, consequently, a threat to the functioning of institutions and essential public services and the survival of the population, as well as the risk of a serious disturbance to foreign relations or to peaceful coexistence of nations, or a risk to military interests, may affect public security" (para. 66 of the judgement).

${ }^{9}$ On the subject of detention of irregular migrants, see: Kosińska, 2015, pp. 51-68.

${ }^{10}$ In accordance with Art. 6(2): "Third-country nationals staying illegally on the territory of a Member State and holding a valid residence permit or other authorisation offering a right to stay 
also obligated to conduct an individual assessment in order to ascertain whether the personal conduct of the third-country national concerned posed a genuine and present risk to public policy (Case C 240/17, para. 49; see also: Kosińska, 2016). In the case of the lack of response from the Spanish authorities to the consultation procedure (which should facilitate a foreign national's return to the Member State which had issued him the residence permit), the Finnish authorities acted in accordance with the Union's law, issuing a decision to return to $\mathrm{Mr} \mathrm{E}$.

Moving further, in the case C 369/17 the CJEU interpreted Art. 17 Directive 2011/95 concerning the exclusion from eligibility for subsidiary protection. ${ }^{11}$ In accordance with the above provision, exclusion from subsidiary protection may occur, amongst others, in the case when a foreign national "constitutes a danger to the community or to the security of the Member State in which he or she is present" (Art. 17(1)(d) Directive 2011/95/EU). In the proceedings, the Court interpreted the term "serious crime," the perpetration of which constituted a circumstance allowing for the exclusion of the foreign national from eligibility for subsidiary protection. The question for a preliminary ruling was referred to the CJEU by the Hungarian court, whereas the national proceedings concerned a national of Afghanistan convicted in criminal proceedings for attempted murder and an attempt at extortion. The Court ruled that the basis for the assessment of the "seriousness" of the committed crime lies not only in the duration of the penalty provided for under national law. In the case of exclusion from international protection the authorities of the Member States are obligated to individually assess all the circumstances of each case (Case C 369/17, para. 58).

The issues of the threat to public order and internal security was also the subject of the case $\mathrm{C} 444 / 17$. The question from the French court referred for a preliminary ruling regarded the situation of the reintroduction of border control at internal borders by France in 2016 on the basis of Art. 25 of the Schengen Code (Regulation 2016/399). ${ }^{12}$ The French court wanted to determine whether the situation of the reintroduction of border controls permits the exclusion of the application of the provisions of the Return Directive on the grounds of its Art. 2(2). This would result in the possibility of dispensing with the application of full guarantees and procedures in the realization of the TCN's return. In the present case the CJEU examined primarily the possibility of applying the provisions of the Return Directive for the internal borders of the Member State and issued an answer in the negative. The exclusion of the application

issued by another Member State shall be required to go to the territory of that other Member State immediately. In the event of non-compliance by the third-country national concerned with this requirement, or where the third-country national's immediate departure is required for reasons of public policy or national security, paragraph 1 shall apply."

${ }_{11}$ In the proceedings, the Court interpreted the term "serious crime," the commitment of which constituted a circumstance allowing for the exclusion of the foreign national from eligibility for subsidiary protection.

${ }^{12}$ Accordingly: "Where, in the area without internal border control, there is a serious threat to public policy or internal security in a Member State, that Member State may exceptionally reintroduce border control at all or specific parts of its internal borders for a limited period of up to 30 days or for the foreseeable duration of the serious threat if its duration exceeds 30 days. The scope and duration of the temporary reintroduction of border control at internal borders shall not exceed what is strictly necessary to respond to the serious threat." 
of Art. 2(2) in fact allows the Member States to apply agreements on readmission and thus facilitate a fast return of persons with regard to whom an entry ban was issued or those who are subject to criminal sanctions. However, in view of the Court, the concepts of the "external border" and the "internal border" are mutually exclusive. Nevertheless, the Court emphasized in its ruling that there exists a possibility of applying detention or arrest with regard to TCNs residing illegally in the territory of a Member State or remaining subject to the return procedure if such a person might pose a threat to public order or internal security (Case 444/17, para. 66).${ }^{13}$ Thus, the Court supported the interpretation issued in the case of Affum (Case C 47/15). ${ }^{14}$

Secondly, the case-law of the CJEU also includes the issues of limiting the entry or the possibility of free movement of third-country nationals. In the context of the issues pertaining to the migration security, the judgment in the joined cases $C 443 / 14$ and C 444/14 is especially controversial and interesting. The proceedings concerned Syrian nationals, who were granted subsidiary protection in Germany. In accordance with the national law, the foreign nationals were imposed an obligation to find residence with the exception of the capital of the Land of Lower Saxony. The applicants claimed that such residence conditions were in breach of the right to freedom of movement under Art. 33 of the Qualification Directive. On the other hand, the authorities of the Land argued that the purpose of the said regulation is the fair division of social burdens and the prevention of social conflicts. Thus, indirectly, the aim of the German regulation was to guarantee civil and social security. The Court interpreted Art. 33 Directive 2011/95 in the light of Art. 26 of the Geneva Convention (The Convention Relating) and found that that the beneficiaries of international protection should be ensured both the right to freedom of movement as well as the right to the choice of residence (Case C 443/14 and C 444/14, para. 40). However, the limitation of the place of residence is permissible and in accordance with the Union's law in the case when it is aimed at facilitating the integration of third-country nationals in the host country. Thus, the Court held that achieving a general objective justifies the derogation of the migrant's right to the freedom of movement (Answer to the third question referred for a preliminary ruling in the joint cases C-443/14 and C-444/14).

Next, in the case C 331/16 the Court examined the case of a national of Croatia, remaining at the same time a national of Bosnia and Herzegovina, who applied in the Netherlands for revoking his ban on entry issued before Croatia joined the EU. Mr K was found guilty of committing the acts described under Art. 1(F)(a) of the Geneva Convention (crime against peace, war crime or crime against humanity), while the

${ }^{13}$ In the case-law of the CJEU the problem of criminalization of irregular migration has also been present for many years. In accordance with the line of jurisprudence of the Court, in the case of the decision on a custodial measure regarding a TCN, merely an illegal stay is not an adequate circumstance. The decision on detention should be in each case preceded by "individual assessment" - see: Strąk, 2018, p. 19. See: Case C 61/11 PPU, Hassen El Dridi [28.04.2011], EU:C:2011:268. See also: Peers, 2015, p. 9; Klaus, 2016, p. 170 et seq.

${ }^{14}$ In accordance with the sentence of the judgement, Directive 2008/115 should be interpreted to the effect that: "....a third-country national is staying illegally on the territory of a Member State and therefore falls within the scope of that directive when, without fulfilling the conditions for entry, stay or residence, he passes in transit through that Member State as a passenger on a bus from another Member State forming part of the Schengen area and bound for a third Member State outside that area." 
Dutch authorities decided that "the protection of public policy and public security required that nothing should be left undone to prevent citizens of the Netherlands coming into contact with individuals who, in their country of origin, had been guilty of serious conduct" (Case C 331/16, para. 18), referring to the condition of public order. In the present case the Court examined the possibility of applying with regard to $\mathrm{Mr}$ K Art. 27 of the Citizenship Directive, which allows for the limitation of the freedom of movement of persons on account of the protection of public policy, public security or public health (Art. 27 directive 2004/38) ${ }^{15}$ In an answer to the question referred for a preliminary ruling, the CJEU referred to the concept of "public security," well-established in the case-law, turning attention to its both external as well and internal dimension (Case C 331/16, para. 42). ${ }^{16}$ Nevertheless, the Court emphasized that the very fact that the exclusion from international protection occurred in the past under Art. 1(F) (a) of the Geneva Convention cannot automatically permit the finding that the mere presence of such a person might constitute "a genuine, present and sufficiently serious threat affecting one of the fundamental interests of society" (Case C 331/16, para. 51). In this way, the Court pointed out to the necessity of "individual assessment" and the application of the principle of proportionality in the case of restricting third-country nationals' fundamental rights. Individual assessment of the situation of a foreign national is also required for the issuing of the decision to expel a foreign national from the territory of the Member State. In a similar way, the Court ruled in the cases directly related to the exclusion from international protection. Thus, in the case of Lounani, the CJEU held that the acts consisting in the participation in the activities of a terrorist group might be a circumstance for exclusion from international protection; however, it is the obligation of the authorities of the Member States to conduct an individual assessment of the situation of a third-country national (Case C 573/14). ${ }^{17}$

Thirdly, after 2015, the Court also voiced its opinion on the subject of the bans of entry issued with regard to third-country nationals on the grounds of the provisions of Directive 2008/115 (Art. 11 Directive 2008/115). In the case C 82/16 the proceedings concerned a group of third-country nationals, who were issued return decisions together with the ban on entry into the territory of the Union, whereas the said foreign nationals were members of the family of a citizen of the Union. The Court had thus to decide whether the good requiring protection in that case were the citizen's rights resulting from the treaties and secondary law or the protection of public order. The Court ruled that those terms should be interpreted in a strict way (Case C 82/16, para. 91). ${ }^{18}$ The Court also confirmed that an assessment whether a given person is

15 The CJEU interpreted Art. 27 directive 2004/38 also in the judgement in the case Case C 184/16, Ovidiu-Mihaita Petrea v Ypourgou Esoterikon kai Dioikitikis Anasygrotisis [14.09.2017], EU:C:2017:684.

${ }^{16}$ As the CJEU stated: "Internal security may be affected by, inter alia, a direct threat to the peace of mind and physical security of the population of the Member State concerned (see, to that effect, C 348/09, [2012], EU:C:2012:300, paragraph 28). As regards external security, that may be affected by, inter alia, the risk of a serious disturbance to the foreign relations of that Member State or to the peaceful coexistence of nations (see, to that effect, C 145/09, Tsakouridis [23.11.2010], EU:C:2010:708, paragraph 44)."

${ }_{17}$ On this subject see also: Y. Li, 2017.

${ }^{18}$ In accordance with the opinion and the established case-law of the Court: "the concept of 
posing a threat to the security should be carried out not in an automatic but on a caseto-case basis, in accordance with the principle of proportionality and in the light of fundamental rights, with a special focus on the rights of the child and the right to respect for family life (Case C 82/16, para. 93).

The ban on entry and the interpretation of Art. 11 Directive 2008/115 in the case of bans issued before the directive entered into force was the concern of the judgement in the case C 225/16. In accordance with the above Article, the ban on entry is issued in principle for the period not exceeding 5 years, but the period may be longer in a situation when a foreign national poses a "serious threat to public policy, public security or national security" (Art. 11(2) Directive 2008/115). The situation of the foreign national in this case was specific in as much as after he was issued a return decision together with an accompanying ban on entry, he did not in fact leave the territory of the Member State but remained there illegally. The Court, in an answer to the question referred for a preliminary ruling stated that "the starting point of the duration of an entry ban, as referred to in that provision, which in principle may not exceed five years, must be calculated from the date on which the person concerned actually left the territory of the Member States" (Case C 225/16, para. 58). In the discussed case, the Court referred to the previous ruling concerning the ban on entry with regard to the case of Filev and Osmani (Case C 297/12; see also: BasilienGainche, 2015, p. 108; Costello, 2016, p. 299 et seq). It should be pointed out at this stage that before the Return Directive entered into force, the Member States (such as, e.g. Germany) had the possibility of issuing permanent entry bans (See also: Opinion of Advocate General C 225/16, para. 77-78). As the Advocate General pointed out in her opinion, the authorities of the Member States should assess whether the decision on the entry ban had been issued in full respect of fundamental rights as the general principles of EU law.

Fourthly, since April 2015, the Court of Justice of the European Union has been dealing with cases directly related to the social phenomena and legal issues accompanying the management of the European migration crisis. Those cases to a large extent concerned the issues of sharing responsibility in the spirit of solidarity by the Member States in the face of the mass influx of migrants and therefore ensuring migration security in the territory of all Member States (See also: C 646/16, C 490/16). In this extraordinary situation experienced by the Member States, it was especially important to guarantee security to all parties of the migration processes - both migrants themselves, as well as the receiving society. A specific general clause concerning the governance of crisis migrations might be found under Art. 80 of the Treaty on the Functioning of the European Union (Treaty on the Functioning), in accordance with

\footnotetext{
'public policy' presupposes, in any event, the existence, in addition to the disturbance of the social order which any infringement of the law involves, of a genuine, present and sufficiently serious threat affecting one of the fundamental interests of society. As regards the concept of 'public security,' it is clear from the Court's case-law that that concept covers both the internal security of a Member State and its external security, and, consequently, a threat to the functioning of institutions and essential public services and the survival of the population, as well as the risk of a serious disturbance to foreign relations or to peaceful coexistence of nations, or a threat to military interests, may affect public security."
} 
which the Union's migration policy relies on the principle of solidarity and an equitable burden-sharing between the Member States. ${ }^{19}$ Thus, the solidarity of the Member States is a guarantee of ensuring migration security in the territory of the Union.

The issue of the management of migration flows and the legal measures adopted for that purpose at the level of the Union was the concern of the CJEU in the examination of the complaint lodged by the Slovak Republic and Hungary for the annulment of the decision on the relocation of migrants from the Member States experiencing the largest migration pressure, i.e. Italy and Greece (Council Decision (EU) 2015/1601). The above Member States raised several arguments in this matter with a view to proving the decision invalid, referring to, amongst others, an infringement of the principle of proportionality, infringement of the procedural requirements, as well as the fact that "the contested decision does not satisfy the condition for the application of Article 78(3) TFEU" (Joined Cases C-643/15 and C-647/15, para. 104 et seq). While examining the case, the Court referred to the content of the decision on relocation, as, in accordance with its Preamble:

National security and public order should be taken into consideration throughout
the relocation procedure, until the transfer of the applicant is implemented. In
full respect of the fundamental rights of the applicant, including the relevant
rules on data protection, where a Member State has reasonable grounds for re-
garding an applicant as a danger to its national security or public order, it should
inform the other Member States thereof (Case C $643 / 15$ para. 12, recital 32 Pre-
amble to Decision 2015/1601).

The Court also emphasized that in accordance with Art. 5(7) of the decision: "Member States retain the right to refuse to relocate an applicant only where there are reasonable grounds for regarding him or her as a danger to their national security or public order" (Art. 5(7) Decision 2015/1601). The circumstance of the protection of security and public order as justifying the lack of implementation of the decision on relocation was also raised in the proceedings by the Republic of Poland (Case C 643/15, para. 306). The Polish government held that the realization of Art. 5(7) of the decision would be ineffective due to the necessity of verifying a large number of persons in a short amount of time. According to the Court, such an argument could not be accepted whereas the whole procedure of relocation should be carried out "in the spirit of cooperation and mutual trust between the authorities of the Member States" (Case C 643/15, para. 306). Solidarity and trust between the Member States are the values on which the Court based its reasoning for the above ruling. Advocate General Yves Bot spoke extensively on the subject of the significance of the principle of cooperation in the spirit of solidarity in the face of the crisis. In his opinion on the matter in question, the Advocate General described solidarity as a founding and existential value of the European Union (Opinion of Advocate General Case C 643/15 and C 647/15). Moving further, he observed that: "More specifically, solidarity is both a pillar and at the same time a guiding principle of the European Union's policies on border checks,

${ }^{19}$ Additionally, in accordance with Art. 78(3) TFEU: "In the event of one or more Member States being confronted by an emergency situation characterised by a sudden inflow of nationals of third countries, the Council, on a proposal from the Commission, may adopt provisional measures for the benefit of the Member State(s) concerned. It shall act after consulting the European Parliament." 
asylum and immigration, which form the subject matter of Chapter 2 of Title $\mathrm{V}$ of the FEU Treaty, devoted to the area of freedom, security and justice" (Opinion of Advocate General Case C 643/15 and C 647/15, para 20). ${ }^{20}$ Thus, it seems that it will not be an exaggeration to claim that the cooperation of the Member States in the spirit of solidarity in the implementation of migration policies might be recognized as one of the guarantees of migration security.

\section{Conclusions}

The analysis of the case-law of the CJEU was intended to demonstrate the level of implementation of the principle of the migration security priority with regard to the protection of the interests of the Member States in the area of ensuring public security in the Member States in the face of the migration crisis. The selected fragment of the line of jurisprudence of the CJEU in the cases concerning migration illustrates the tendency currently to be observed in political discussions, namely that of the reorientation of the debate from the focus on migration to the focus on security (Trojanowska-Strzęboszewska, 2018, p. 5) and securitization of migration (Spijkerboer, 2017, p. 16).

On the basis of the analysis of the above rulings regarding the migration security of the Member States, one can formulate the following general conclusions:

Firstly, the cases brought before the Court of Justice provide a benchmark for migration problems and might provide grounds for diagnosing the problems related to the implementation of migration law in particular Member States. The cases discussed in the present article, especially case C $643 / 15$ and C $647 / 15$ point out to the problem of different experiences of the Member States in migration management. What is the consequence of those various experiences and expectations as to the migration governance at the level of the Union is the difficulty in reaching compromise and in ensuring a solidarity-based participation in the alleviation of the effects of the mass influx of migrants into the EU (see also: Estevens, 2018, p. 18). At present, this problem seems to be indeed very difficult to solve, primarily due to the fact that at the time of the escalation of the migration crisis, the Union did not have any effective legal instruments to manage the crisis and the propositions of changes appeared too late and still remain at the stage of the legislative procedure. ${ }^{21}$

Secondly, the current rulings of the CJEU with regard to the security of the Member States allow for the assessment of the existing challenges and threats transpiring from asylum and return migrations. The problem which is faced by the Member States is the presence of the so-called undesirable migrants on their territory, who can pose a threat

${ }^{20}$ What is more, AG also emphasized the impact of the decision on the observance of migrants' fundamental rights: "It participates in the preservation of the fundamental rights of applicants in clear need of international protection, as guaranteed by the Charter, and in particular by Article 18 thereof, by transferring them to Member States, other than the Italian Republic and the Hellenic Republic, which are in a better position to process their applications" (para. 335 opinion, sent. 2).

${ }^{21}$ This concerns primarily the legislative proposals of the qualification and procedural regulations for the asylum procedure and Dublin IV regulation presented in 2016. 
to security and public order. In the cases discussed above, the Court allows for the application of entry bans and detention for the purpose of preparing the return (see also: Burek, Markiewicz-Stanny, 2016, pp. 208-229; Szuniewicz, 2016, p. 188 et seq.) and exclusion from international protection. However, in each case the application of such measures should be preceded by an individual assessment of the threat which might be posed by the third-country national - therefore the TCN must pose a genuine and present risk. In the case-law discussed above, the CJEU is balancing between two values: the rights of TCNs and the rights and obligations of the Member State to guarantee the security of the collective subject, i.e. its society.

For the purpose of research carried out in the current project, the structure of the right to migration security as a third-generation right has been formulated. Simultaneously, a postulate of incorporating the concept of the right to migration security into the legal discourse on migration management within the EU was proposed (Kosińska, Mikołajczyk, 2019). This right finds its axiological basis in the EU legal system, i.e. in the treaty provisions, especially under Art. 3(3) TEU, in accordance with which the EU "shall promote solidarity between Member States" (Treaty on European Union). This right is of a two-fold character and it should protect both the receiving society as well as migrants themselves against the threats coming from migration. The institutions obligated to action and protection are, in turn, EU institutions, including the CJEU. In the context of the rulings discussed above, a reference to the concept of the right to migration security seems to be justified for two reasons - firstly, migration policies (and as a result migration law established by the EU) constitute a competence shared by the EU and the Member States. As C. Costello observes, the EU should thus make legal norms in the area of the shared competences "only when it is demonstrably better at achieving the given objective than the Member State" (Costello, 2016, p. 29). Both the norms of asylum law and return law have been adopted at the level of the EU. On the basis of the above analysis, it also transpires that there exists a need for the interpretation of the legal norms at the level of the EU, which in turn leads to the creation of the EU protection standards. Migration security may thus be strengthened by solidarity-based commitment of the Member States to abide by the norms of migration law and the enforcement of such commitments by the CJEU. Secondly, it seems that the inclusion of the concept of the right to migration security (non-existent to date) into the legal discourse would make it possible for the Court of Justice to interpret the protection standards in the area of migrations security in a broader way (Kosińska, Mikołajczyk, 2019, p. 115). At the same time, it would be possible to highlight the problem of the protection of the receiving society from the perspective of human rights.

In conclusion, it seems that despite the difficulties regarding the attitude of the Member States towards the acceptance of migration governance at the EU level, further cooperation in this area is inevitable. Global migrations require at least a regional system of governance due to its present character and size (Hollifield, Faruk, 2017, p. 131). Hence, the role played by the CJEU (especially the role of questions referred for a preliminary ruling) in establishing common migration security standards by means of the interpretation of the universal and abstract norms of EU law seems to be invaluable (McMahon, 2015, pp. 223-224). 


\section{Bibliography}

Ahmed I. (2017), Migration and Security. In Search of Reconciliation, „Migration Letters” vol. 14, no. 3 .

Basilien-Gainche M-L. (2015), Immigration Detention under the Return Directive: the CJEU Shadowed Lights, "European Journal of Migration and Law", vol. 17.

Burek W., Markiewicz-Stanny J. (2016), Dopuszczalność sankcji karnej pozbawienia wolności za naruszenie zakazu wjazdu przez cudzoziemca - uwagi z perspektywy prawa UE i prawa międzynarodowego praw człowieka, in: Status cudzoziemca w Polsce wobec wspótczesnych wyzwań międzynarodowych, ed. D. Pudzianowska, Wolters Kluwer, Warszawa.

Case C 61/11 PPU, Hassen El Dridi [28.04.2011], EU:C:2011:268.

Case C 297/12, Criminal proceedings against Gjoko Filev and Adnan Osmani [19.09.2013], EU:C:2013:569.

Case C 443/14 and C 444/14, Kreis Warendorf v. Ibrahimowi Alowi and Amira Osso v. Region Hannover [1.03.2016], EU:C:2016:127.

Case C 573/14, Commissaire général aux réfugiés et aux apatrides v. Mostafa Lounani [31.01.2017], C 573/14, EU:C:2017:71.

Case C 47/15, Sélina Affum v Préfet du Pas-de-Calais and Procureur général de la Cour d'appel de Douai [7.06.2016], EU:C:2016:408.

Case C 601/15 PPU, J.N. v. Staatssecretaris van Veiligheid en Justitie [15.02.2016], EU:C:2016:84.

Case C 18/16, K. v. Staatssecretaris van Veiligheid en Justitie [14.09.2017], EU:C:2017:680.

Case C 82/16, K.A. and Others v. Belgische Staat [8.05.2018], C 82/16, EU:C:2018:308.

Case C 184/16, Ovidiu-Mihaita Petrea v Ypourgou Esoterikon kai Dioikitikis Anasygrotisis [14.09.2017], EU:C:2017:684.

Case C 225/16, Criminal proceedings against Mossa Ouhrami [26.07.2017], EU:C:2017:590.

Case C 331/16, K. v. Staatssecretaris van Veiligheid en Justitie and H.F. v. Belgische Staat [2.05.2018], EU:C:2018:296.

Case C 490/16, A.S. v. Republic of Slovenia [26.07.2017], EU:C:2017:585.

Case C 646/16, Khadija Jafari and Zainab Jafari [26.07.2017], EU:C:2017:586.

Case C 240/17, E [16.02.2018], EU:C:2018:8.

Case C 369/17, Shajin Ahmed v. Bevándorlási és Menekültügyi Hivatal [13.09.2018], EU:C:2018:713.

Case C 444/17, Préfet des Pyrénées-Orientales v Abdelaziz Arib and Others [19.03.2019], EU:C:2019:220.

Costello C. (2016), The Human Rights of Migrants and Refugees in European Union, Oxford, Oxford University Press.

Council Decision (EU) 2015/1601 of 22 September 2015 establishing provisional measures in the area of international protection for the benefit of Italy and Greece, OJ EU L 248, 24.9.2015.

Directive 2004/38/EC of the European Parliament and of the Council of 29 April 2004 on the right of citizens of the Union and their family members to move and reside freely within the territory of the Member States amending Regulation (EEC) no. 1612/68 and repealing Directives 64/221/EEC, 68/360/EEC, 72/194/EEC, 73/148/EEC, 75/34/EEC, 75/35/EEC, 90/364/EEC, 90/365/EEC and 93/96/EEC, OJ L 158, 30.4.2004.

Directive 2008/115/EC of the European Parliament and of the Council of 16 December 2008 on common standards and procedures in Member States for returning illegally staying third-country nationals, OJ L 348, 24.12.2008.

Directive 2011/95/EU of the European Parliament and of the Council of 13 December 2011 on standards for the qualification of third-country nationals or stateless persons as beneficiaries of 
international protection, for a uniform status for refugees or for persons eligible for subsidiary protection, and for the content of the protection granted, OJ L 337, 20.12.2011.

Estevens J. (2018), Migration crisis in the EU: developing a framework for analysis of national security and defence strategies, „Comparative Migration Studies”, no. 6.

Fehler Wł., Cebul K., Podgórzańska R. (2017), Migracje jako wyzwanie dla Unii Europejskiej i wybranych państw członkowskich, Wyd. Difin, Warszawa.

Gierszewski J., Pieczywok A. (2019), Społeczny wymiar bezpieczeństwa człowieka, Difin, Warszawa.

Hollifield J., Faruk R. (2017), Governing Migration in an Age of Globalisation, in: Migration on the Move, eds. C. Grutters, S. Mantu, P. Minderhoud, Brill/Nijhoff, Leiden-Boston.

Joined Cases C 643/15 and C 647/15 Slovak Republic and Hungary v. Council of the European Union [6.07.2017], EU:C:2017:631.

Klaus W. (2016), Cudzoziemcy niemile widziani. Detencja cudzoziemców jako przykład kryminalizacji migracji, in: Status cudzoziemca w Polsce wobec wspótczesnych wyzwań międzynarodowych, ed. D. Pudzianowska, Wolters-Kluwer, Warszawa.

Kosińska A. M. (2016), Definicja pojęcia zagrożenia dla porządku publicznego, jakie może stanowić obywatel państwa trzeciego i okoliczności wyznaczania terminu dobrowolnego powrotu cudzoziemca - glosa do wyroku Trybunału Sprawiedliwości z 11.06.2015 r. w sprawie C-554/13 Z.Zh. przeciwko Staatssecretaris voor Veiligheid en Justitie oraz Staatssecretaris voor Veiligheid en Justitie przeciwko I.O., „Europejski Przegląd Sądowy”, no. 2.

Kosińska A. M. (2015), Problem detencji nieudokumentowanych obywateli państw trzecich w kontekście ochrony praw podstawowych migrantów, in: Acquis Return. Doświadczenia implementacji i rozwój polityki powrotowej Unii Europejskiej, ed. A. M. Kosińska, Instytut na rzecz Państwa Prawa, Lublin.

Kosińska A. M. (2017), The Creative Role of the European Council in the Area of Managing Asylum Migration and Return of Third-Country Nationals to Their Country of Origin in the Times of the Migration Crisis, "Yearbook of Polish European Studies", vol. 20.

Kosińska A. M., Mikołajczyk B. (2019), Does the Right to Migration Security Already Exist? Considerations from the Perspective of the EU's Legal System, "European Journal of Migration and Law", no. 1.

Latest asylum trends - 2018 overview (2018), European Asylum Support Office, www.easo.europa. eu/asylum-trends-overview-2018.

Li Y. (2017), Exclusion from Protection as Refugee. An Approach to a Harmonizing Interpretation in International Law, Brill/Nijhoff, Leiden-Boston.

McMahon A. (2015), The Role of State in Migration Control. The legitimacy Gap and Moves towards a Regional Model, Brill/Nijhoff, Leiden-Boston, pp. 223-224.

Opinion of Advocate General Sharpston delivered on 18 May 2017, C 225/16, EU:C:2017:398.

Opinion of Advocate General Bot delivered on 26 July 2017. Case C 643/15 and C 647/15, EU:C:2017:618.

Peers S. (2015), Irregular Migrants: Can Humane Treatment Be Balanced against Efficient Removal?, „European Journal of Migration and Law”, vol. 17.

Regulation (EU) 2016/399 of the European Parliament and of the Council of 9 March 2016 on a Union Code on the rules governing the movement of persons across borders (Schengen Borders Code), OJ L 77, 23.3.2016

Risk Analysis for 2019 (2019), Frontex, Warsaw.

Spijkerboer T. (2017), Changing Paradigms in Migration Law Research, in:, Migration on the Move, eds. C. Grutters, S. Mantu, P. Minderhoud, Brill/Nijhoff, Leiden-Boston.

Stawicki R. (2019), Współczesne bezpieczeństwo człowieka. Dystans społeczny. Uchodźcy. Percepcja zagrożeń, Difin, Warszawa. 
Strąk K. (2018), Pojęcie ryzyka ucieczki w prawie azylowym i imigracyjnym Unii Europejskiej, „Europejski Przegląd Sądowy", no. 2, pp. 18-24.

Szuniewicz M. (2016), Ochrona bezpieczeństwa państwa jako przesłanka ograniczenia praw $i$ wolności jednostki w świetle Europejskiej Konwencji Praw Człowieka, Wydawnictwo C.H. Beck, Warszawa.

The Convention Relating to the Status of Refugees, drafted in Geneva on 28 July 1951, Journal of Laws of 1991, no. 119, item 515.

Treaty on European Union, consolidated version, OJ C 202, 7.6.2016.

Treaty on the Functioning of the European Union, OJ C 202, 7.6.2016.

Trojanowska-Strzęboszewska M. (2018), Paradygmat bezpieczeństwa w polityce migracyjnej UE, „Studia Europejskie”, no. 2, pp. 113-132.

Wawrzyk P. (2014), Bezpieczeństwo wewnętrzne Unii Europejskiej, Wydawnictwa Akademickie i Literackie ŁG, Warszawa.

\section{Summary}

The article analyzes the post-crisis CJEU case-law in the area of migration security of the Member States. Due to the escalation of the migration crisis in 2015, the European Union has been facing new challenges in migration management. The case-law of the CJEU, especially issued in the procedure of the so-called questions referred for a preliminary ruling, constitutes a certain benchmark for the problems, which the Member States need to deal with in the area of guaranteeing safety. In accordance with the research method adopted for the purpose of the current study, the Court of Justice has a real possibility of shaping the standards of migration security in the area of asylum and return policies through its case-law. What is more, within the field of EU migration law and migration policies, there exists a migration security priority, in accordance with which it is necessary to provide the highest level of security to all the actors of migration processes, i.e. both the very migrants, as well as the receiving society. This principle should be applied at the level of legislative processes and also in the area of the implementation of legal norms. As a result of the conducted analysis of the case-law of the CJEU, the four basic areas with regard to the migration security of the Member States have been identified.

Key words: Common European Asylum System, migration security, migration crisis, CJEU case-law

\section{Problem bezpieczeństwa migracyjnego w aktualnym orzecznictwie TSUE - perspektywa państw czlonkowskich}

\section{Streszczenie}

Artykuł analizuje orzecznictwo pokryzysowe Trybunału Sprawiedliwości Unii Europejskiej w obszarze bezpieczeństwa migracyjnego państw członkowskich. W związku z eskalacją kryzysu migracyjnego w 2015 r. Unia Europejska stanęła przed nowymi wyzwaniami w zarządzaniu migracjami. Orzecznictwo TSUE, zwłaszcza wydawane w procedurze tzw. pytań prejudycjalnych, stanowi swoisty barometr dla problemów, z jakimi mierzą się państwa członkowskie w zakresie zagwarantowania bezpieczeństwa. Zgodnie z przyjętymi założeniami badawczymi, Trybunał ma realną możliwość kształtowania standardów bezpieczeństwa migracyjnego w obszarze polityki azylowej i powrotowej. Co więcej, w ramach prawa migracyjnego UE i poli- 
tyk migracyjnych istnieje priorytet bezpieczeństwa migracyjnego, zgodnie z którym konieczne jest zagwarantowanie jak najwyższego poziomu bezpieczeństwa wszystkim uczestnikom procesów migracyjnych, tj. zarówno migrantom, jak też społeczeństwu przyjmującemu. Zasada ta powinna być wdrażana zarówno na poziomie procesów legislacyjnych, jak też w obszarze implementacji norm prawnych. W wyniku przeprowadzonej analizy orzecznictwa Trybunału, wyodrębnione zostały cztery podstawowe obszary związane z bezpieczeństwem migracyjnym państw członkowskich: sprawy dotyczące bezpośrednio ochrony bezpieczeństwa i porządku publicznego, sprawy odnoszące się do możliwości ograniczenia cudzoziemcom niepożądanym wjazdu na terytorium państw członkowskich oraz swobody poruszania się, sprawy dotyczące zakazów wjazdu nakładanych na cudzoziemców o nieuregulowanym statusie oraz problematyki solidarnego dzielenia odpowiedzialności przez państwa członkowskie w obliczu masowego napływu migrantów, a tym samym zapewnienia bezpieczeństwa migracji na terytorium wszystkich państw członkowskich.

Słowa kluczowe: Wspólny Europejski System Azylowy, bezpieczeństwo migracji, kryzys migracyjny, orzecznictwo TSUE 